\title{
BRENDA GAYLE PLUMMER. In Search of Power: African Americans in the Era of Decolonization, 1956-1974
}

Robert T. Vinson

Follow this and additional works at: https://scholarworks.wm.edu/aspubs

Part of the Africana Studies Commons, and the African History Commons

\section{Recommended Citation}

Vinson, Robert T., BRENDA GAYLE PLUMMER. In Search of Power: African Americans in the Era of Decolonization, 1956-1974 (2014). The American Historical Review, 119(3), 828-830.

https://doi.org/10.1093/ahr/119.3.828

This Book Review is brought to you for free and open access by the Arts and Sciences at W\&M ScholarWorks. It has been accepted for inclusion in Arts \& Sciences Articles by an authorized administrator of W\&M ScholarWorks. For more information, please contact scholarworks@wm.edu. 
ators and washing machines were coded female, and the TV was familial, the Beetle was distinctly male. If Germans associated Volkswagen with the Third Reich, some remembered the Kübelwagen as a useful aid to the ostensibly "clean" Wehrmacht in its African campaigns. Others saw the Beetle as proof that the Federal Republic was superior to Nazi Germany, for it realized the latter's promise of an affordable small car.

For some Americans, purchasing the unconventional, ugly, or at least aesthetically confusing Beetle represented a revolt against the extravagances of American consumer modernity and cars with chrome and tailfins. For others, the Beetle supplemented the family's orthodox American model, for use by a suburban wife or teenage children. Americans conferred the name "Beetle" or "Bug" on the People's Car, a name that migrated back to Germany. While Germans stressed the car's reliability and "German quality work," the primarily middle-class American owners loved the Beetle for its cute look, quirkiness, and diminutive proportions. Recall the famous "think small" ad. For many, the Beetle still evokes nostalgic memories of the 1960s. Because the Beetle arrived when the American auto industry was thriving and remained a niche product with a 3 percent market share, it did not arouse the antipathy that Japanese auto imports were to do during the crisis-ridden 1970s.

While Americans always acknowledged the Beetle's foreign origins, the Mexican middle class embraced $\mathrm{el}$ vochito, as it was fondly called, as a thoroughly national commodity. It was produced in Mexico, by Mexican workers; its sturdy construction and reliability made it ideal for Mexico's harsher driving conditions and lessdeveloped service infrastructure. Most importantly, ever-larger sections of the middle class could afford the Beetle, which paved the way for mass motorization as it had in Germany. As in the U.S., and to a lesser extent Germany, the Beetle was an object of affection and nostalgia, as well as of national pride. Regrettably, Rieger does not explore how it was gendered in Mexico.

The Beetle could so comfortably assimilate to different national cultures, Rieger concludes, because Volkswagen, for understandable reasons, did not confidently project its origins in the postwar world. American goods, by contrast, gained their cachet by evoking distinctively American lifestyles. Yet, as studies have shown, American global commodities like Singer sewing machines and McDonald's hamburgers and fries acquired very different uses and meanings when they moved abroad. Their Americanness may have been a source of appeal, but it was the intersection and inequalities of local and global capitalism, the nature of national consumer cultures, and the actions of individual consumers that affected their appropriation and transformation. Americanization may share a lot with the internationalization of Volkswagen and the biography of the Beetle.

MARY NOLAN New York University

\section{Brenda Gayle Plummer. In Search of Power: African Americans in the Era of Decolonization, 1956-1974. New York: Cambridge University Press. 2013. Pp. vii, 372. $\$ 29.99$.}

Recent work by Gerald Horne, Carol Anderson, Kevin Gaines, Penny Von Eschen, Thomas Borstelmann, and Mary Dudziak, among others, has placed the modern U.S. civil rights era in a Cold War global context. Over the course of her sterling career, particularly with works like Rising Wind: Black Americans and U.S. Foreign Affairs, 1935-1960 (1996) and her edited collection Window on Freedom: Race, Civil Rights, and Foreign Affairs, 1945-1988 (2003), Brenda Gayle Plummer has transformed the historiographies of U.S. foreign relations, diplomatic history, Cold War studies, and African American history with her explorations into how African American activism influenced U.S. policymakers to grapple with the importance of race globally and the linkages between domestic racism and foreign affairs. Plummer has demolished previous assumptions by both U.S. policymakers and scholars that African Americans were uninterested in and uninformed about international affairs and, by corollary, that racism against African Americans was a domestic problem not subject to global scrutiny. Her latest classic, In Search of Power:
African Americans in the Era of Decolonization, 19561974, advances these multiple historiographies and reframes traditional nation-state periodization, calling what is commonly known in African American history as the civil rights/black power period "the era of decolonization." Moving away from nation-state periodization is the next challenge in transnational history, a still-developing field that features audacious geographical expansion but often remains saddled by conventional nation-bound time frames. Writing in the rich Du Boisian tradition of centering black peoples within the global struggle for decolonization and citizenship rights, Plummer engages and transcends the multiple historiographies of African American history, African diaspora studies, African history, Cold War studies, and the history of U.S. foreign relations. She set out to write a Foucauldian "history of the present," and she succeeds admirably: this magisterial work is an instant classic, a tour de force that examines why and how global black movements demanded substantive change, what 
they accomplished, and what historical lessons can be drawn from this global drama.

The book's nine chapters move nimbly among the American, African, Asian, and Caribbean contexts and engage multiple themes, including race, diplomacy, politics, labor, education, culture, and Pan-Africanism. Plummer begins her narrative at a critical historical moment. By 1956, post-World War II, anti-communist government repression had slowed desegregation efforts by targeting progressive trade unions and human rights organizations like the Sojourners for Truth and Justice, the National Negro Congress (NNC), the Civil Rights Congress (CRC), and the Council on African Affairs (CAA). Demands for political and socioeconomic human rights were reduced to a narrower struggle for civil rights, defined as legal equality. Likewise, postwar U.S. assistance to England and France slowed decolonization by strengthening those colonial powers, and Cold War geopolitics would subsequently conflate African and Asian nationalism with Moscow-directed communism. In this context, Plummer explores how, "[h]aving predicated national security on the bedrock of racial domination, the [U.S.] was bound to maintain the pattern. The only way out was to readjust the basic premise so that security now required racial justice in order to prevail" (p. 11). While white (and some more conservative black) elites acknowledged the inevitability of at least moderate civil rights reform and gradual decolonization, black transnationalists envisioned the complete political, socioeconomic, and educational empowerment of blacks domestically and the creation of sovereign African, Caribbean, and Asian states. Plummer rightly describes In Search of Power as "a hybrid history" (p. 12), one that illustrates how power operates on multiple levels as it considers the ideas, actions, and perspectives not just of presidential administrations, as many diplomatic histories have done, but also of a range of government leaders, moderate civil rights activists, Pan-Africanist-minded black nationalists, Marxist-oriented radicals, working-class folk, intellectuals, and students throughout North America, Africa, and the Atlantic world.

Plummer's expanded conceptual and geographical framework features activists like Malcolm X and members of the Student Non-Violent Coordinating Committee (SNCC), who defined American blacks as colonized subjects. More interested in black nationalism than in racial integration, such activists "situated their ... struggles in the context of anticolonial resistance, neocolonial domination, and racism" (p. 206). Thus, Plummer is among a growing number of scholars who reformulate the conventional chronology of the civil rights/black power era, demonstrating that ideas of black sovereignty and self-determination associated with black power operated alongside and within, not after, the civil rights movement of the 1950s and 1960s. She begins by examining the intense engagement of Malcolm X and the Nation of Islam with African decolonization to demonstrate the continued vitality of the earlier black internationalist tradition exemplified by persecuted groups like the CAA. Bypassing U.S. government channels, they engaged directly with African leaders to forge a transnational alliance to bring international pressure against American racism and to offer their skills in the service of African nation-building. Building on Winston James's Holding Aloft the Banner of Ethiopia: Caribbean Radicalism in Early TwentiethCentury America (1998), which trenchantly notes the connections between Caribbean radicalism and African American history, Plummer reminds us that this was also an age of Caribbean decolonization and uses a hemispheric framework to better illuminate the connections between black radicalism in the United States, Canada, and the (mostly British) Caribbean and the coordinated surveillance of this radicalism by North American governments.

Plummer's hybrid history also captures the rich, diverse, and complex global dimensions of African American freedom struggles, part of a long historical tradition of enlisting international allies in the work of eliminating domestic racial oppression. She skillfully surveys the kaleidoscopic range of black opinions, ideologies, and organizations, and offers a particularly nuanced portrait of black power politics, which emerges not "as a single set of historical events or rhetorical practices" but "as a complex and varied politics executed by numerous and not necessarily connected actors" (p. 17). A wide array of black power figures visited Tanzania, including SNCC leader James Forman, who was at the forefront of a "skills bank" through which emigrating African Americans provided tangible skills to aid in nation-building projects; Congress of Racial Equality (CORE) leader Roy Innis, who eventually supported segregation and aligned with the Nixon White House; and Marxists, who clashed with black nationalists during the Sixth Pan-African Conference in 1974. Meanwhile, black elected officials like Charles Diggs and Adam Clayton Powell attempted to influence U.S. foreign policy toward newly independent African countries and to quicken decolonization in southern Africa. Plummer examines civil rights leaders like Martin Luther King, Jr., who also organized against apartheid in South Africa and escalating American engagements in the Vietnam War. Moderate blacks engaged Africans through philanthropic and educational channels, seeking to be political and cultural brokers who could lobby effectively on African affairs and also push for more black representation and influence in the American foreign policy apparatus.

African Americans searching for power on the global stage faced daunting obstacles. U.S. presidents John F. Kennedy and Lyndon B. Johnson sought to mainstream African Americans into an envisioned integrationist America while simultaneously denying them their citizenship rights in attempting to influence and participate in U.S. foreign policy, particularly toward newly independent African and Caribbean states. Thus, on the very same day as the 1963 March on Washington, President Kennedy authorized weapons sales to apartheid South Africa. U.S. government officials seemed to 
presume that the price of African Americans' freedom was their complete identification with and obedience to the nation-state, including acquiescence to U.S. foreign policy. In fact, even as the U.S. government marginalized African Americans, U.S. blacks continued to be viewed as a supposed threat to national security and subjected to intensive surveillance at home and abroad.

Other challenges included changing power dynamics between African Americans and African states as the latter privileged state-led Pan-African projects over transnational political agendas emanating from the diaspora. Prior to African independence, many black Americans engaged with Africa regarded themselves as leaders in a "racial uplift" mission to "civilize" Africans. Emphasizing commonalities based on race and a shared history of oppression and exploitation, they hoped that a strong, independent Africa could use its ascendant power to advocate for African Americans on a global stage. Now, as clear junior partners in this transnational relationship, African Americans offered their technical, educational, and political skills to assist in nationbuilding projects. Recalling the Sixth Pan-African Conference, SNCC veteran Judy Claude remembered the abiding concerns of the day: "The question was, did we in the diaspora have anything we could offer Africa? Did we bring skills that we could offer? By building these ties with Africa and strengthening them, would they be of assistance to those of us in the diaspora? Would they deal with our circumstances so that we could always say that we had support of African countries, whether at the UN or at other international forums? We would always raise questions about the conditions of descendants in other parts of the world. That was the idea" (p. 322). But alas, the relative weakness of newly independent African states like Kwame Nkrumah's Ghana and Julius Nyerere's Tanzania, and their preoccupation with their own pressing issues of promoting economic development, quelling domestic dissent, navigating tense relationships with the powerful United States, and negotiating Cold War geopolitics, meant that despite being sites of African American exile and Pan-African engagement, they could not offer all that African Americans had hoped.

A broad anti-white-supremacist framework that referenced historical legacies of slavery and fought against a global color line of colonialism, segregation, and racial capitalism mobilized black peoples worldwide and minimized the importance of disparate transnational ideologies, objectives, and methodologies. This framework facilitated coordinated action against white colonialism in southern Africa, particularly apartheid South Africa, where post-Sharpeville government crackdowns on nonviolent direct action tactics made armed struggle in southern Africa a broadly accepted approach at precisely the time that nonviolent direct action was most popular in America. But black transnationalism viewed through familiar racial binaries meant limited aware- ness and action during the Nigerian Civil War and muted criticism of the kleptocracy that was Zaire, a U.S. Cold War client state, even when the global spotlight turned on Zaire as it hosted the famed "Rumble in the Jungle" championship fight between heavyweight boxers Muhammad Ali and George Foreman.

Plummer argues that African American and African demands for the end of structural racism, colonialism, and imperialism were not fully realized but nevertheless forced global elites to eliminate some forms of state-sponsored racial discrimination, recognize African American citizenship rights, and admit newly decolonized states into the global family of nations. She concludes with the sobering assessment that decolonization "has . . . been a process capable of reversing itself and has in the current age taken on the character of an infinite loop, leaving millions still searching for power" (p. 349). Plummer suggests that those millions must, while drawing appropriate historical lessons, continue to organize transnationally: "a successful emancipatory global politics must break free of its auxiliary relationship to the state" (p. 23).

Plummer makes real the promise of transnational history, moving beyond abstract "notions of ideas" and ideologies to illustrate and interrogate the concrete connections between peoples, organizations, and ideals across the globe. She expands the conceptual, temporal, and geographical range of this burgeoning field, also uncovering forms of white transnationalism, such as coordinated Canadian-American government surveillance and U.S. senator Harry Byrd's support for Ian Smith's Rhodesia. Plummer's research is characteristically stunning in its breadth and in its depth; one clearly gets the sense that she engaged unusually closely and carefully over many years with a wide range of archival sources, newspapers, organizational records, oral interviews, government records, private papers, dissertations, and multiple historiographies. While historians of transnationalism must also make use of a wide range of international archives, Plummer demonstrates that an exhaustive combing of domestic archives can yield extensive and insightful transnational stories. Even in a comprehensive book of 349 pages, themes of gender and sexuality could be further developed, as could other tantalizing topics such as the depoliticizing nature of Blaxploitation films as part of the cultural trivialization of black power figures like Angela Davis. But some underdevelopment of one or two themes is inherent in an ambitious transnational history such as this one, in which we gain so much more than we lose. In Search of Power bears witness to a master historian at the top of her craft; it is a book that rewards close and repeated reading and will, I suspect, remain a "must-read" for transnational historians for many years to come.

Robert TREnt Vinson College of William and Mary 